\title{
Korean Public Rental Housing for Low-income Households: Main Outcome and Limitations
}

\author{
Mee-Youn Jin $^{1}$ and Seok-Je Lee ${ }^{2}$ \\ (Received August 20, 2013 / Revised October 29, 2013 / Accepted October 29, 2013)
}

\begin{abstract}
This paper examines the achievements and limitations of housing assistance programs for low-income households. Korean public rental housing has been rapidly developing since 2000, and thereby achieved an increase in public rental housing stock, housing quality improvements, and the reduction of rent over-burden for low-income tenants. Despite some conflicting evidence, it appears that the provision of newly-built public rental housing has helped stabilize the prices of neighboring private rental housing units. But, as we are entering an era of one million long-term public rental housing units, we need to shift our focus from quantity-oriented provision to housing maintenance for tenants, and from cost-based rental housing to affordable rental housing and better access to rental housing for low-income tenants who are not beneficiaries of government assistance. Most of all, it is very important for local governments and the private sector to actively participate in the provision of public rental housing in order to ensure a stable rental housing market.
\end{abstract}

Key words: Public Rental Housing, Low-Income Tenant, Housing Welfare, Housing Assistance Program

\section{Introduction}

South Korea's housing policy system can be characterized by its orientation to market liberalism. Over the past three decades, since the 1970s, the Korean government has been promoting homeownership under the motor of "One house for one household" and most of the means were distribution policies including new housing construction, funding assistance, housing market activation, and promotion of opening housing subscription deposit accounts. The start of housing stabilization and housing welfare for the low-income households was the introduction of permanent public rental housing or YongGu Public Rental Housing as a way to upgrade the deteriorated housing quality of those in need caused by severe housing shortages, chronic speculation, and skyrocketing housing prices at the end of the 1980s. And the 1997-1998 Asian economic crisis resulted in mass unemployment and economic downturn. In order to tackle the economic difficulties, the government initiated the "One Million Kookmin Public Rental Housing Project,' which strengthened the institutional framework for housing stabilization and housing welfare for ordinary people.

The housing policy of the current government is focused on 'Universal Housing Welfare', which represents its will to take more responsibility for housing provision to all households with housing difficulties instead of taking a residual approach to housing welfare. The government's public rental housing provision is targeting more toward those in desperate need of housing to enhance the publicness of housing. In 2014, the government will introduce a housing voucher program as a new means to provide housing to those excluded from current housing welfare systems.

There are two general types of housing provision for lowincome houseless families: loan support programs financed by the National Housing Fund and programs such as public rental housing. Regrettably, the achievements made by these programs and any possibility of aligning with new programs were not discussed at the government level prior to the introduction of new ones. This suggests that Korea's housing welfare has not matured yet, only focusing on quantitative performance, and it still has a long way to go. Yet in a sense, such immaturity seems to be occurred due to the lack of connectivity among programs based on different master plans proposed by different governments.

Against this backdrop, this paper examines the achievements made by these programs through the review of current housing assistance for low-income households in Korea and identifies challenges ahead. It would be meaningful, at the time of policy

1) Research Fellow, Land \& Housing Institute (Main author: myjin@lh.or.kr)

2) Research Fellow, Land \& Housing Institute (Corresponding author: sjlee1@lh.or.kr) 
transition, to examine in terms of the desirable future direction of housing policies for low-income families and corrective actions necessary to be taken.

This paper has five sections: Section 2 will explain Korea's low-income households and their quality of housing. Section 3 will examine the current housing assistance programs for low-income families and the characteristics of each program. Section 4 will review the achievements made and limitations. The last section will conclude with discussions on future policy directions.

\section{The Housing Condition of Low-income Households in Korea}

\subsection{Defining Low-income Households and Households in Need of Housing Support}

In general, "low-income households" are defined based on two criteria: absolute criterion and relative criterion. Absolute criterion is based on the poverty line (the minimum cost of living) determined by the government). The households under the poverty line are defined as low-income households. Meanwhile, relative criterion is based on median income. The households in the bottom 50 and 80 percent bracket are classified as lowincome households. According to the absolute criterion, the absolute poverty class in Korea is households with income less than the minimum cost of living defined by the National Basic Living Security Act, and are so-called "extremely low-income households." And according to the relative criterion above, low-income households are those with the 70 percent or lower level of monthly average gross income of urban workers. However, housing assistance programs define the bottom four deciles of income as low-income households.

The scope of low-income households was first proposed from the perspective housing policy in 1989 when the YongGu Public Rental Housing, Korea's first social housing, was introduced. After discussion on who should be eligible for the YongGu Public Rental Housing, recipients of basic living (formerly known as recipients of livelihood program), households with income less than the minimum cost of living, were selected as eligible residents. In other words, YongGu Public Rental Housing became a public housing program for the poorest families in the country. In 1990 when a chonsei loan assistance program for low-income households was established, the scope of eligible residents was broadened to include households with less than acertain level of annual income. Since 2003, with the expansion of Kookmin Public Rental Housing, asset-based criteria began to be applied along with income-based criteria, meaning that the definition of low-income households now encompasses both income poverty and asset poverty.

Meanwhile, the concept of low-income household solely based on income has various names including the housing poor, the housing vulnerable, the housing disadvantaged, and the socially vulnerable since the 1998 Asian financial crisis when the multidimensionality of poverty came to the fore. These are general terms referring to "housing class" or "underclass" in Korea that appeared with the emergence of various housing problems: deteriorated housing units that do not meet the minimum housing requirements; rough sleeping in dosshouses, vinyl greenhouses, private dormitories, or inns, and; homelessness. And the Public Assistance System focusing only on households with income less than the minimum cost of living has limited coverage due to strict requirements regarding income level, asset amount, and number of dependents. The households not covered by such a government housing assistance program but in need of housing assistance are called "the secondary poor (households with an income of 100 to 120 percent of the minimum cost of living)" or "the tertiary poor (households with an income of 120 to 150 percent of the minimum cost of living)".

Currently, the government is deciding the eligibility for government housing assistance based not only on economic vulnerability such as income and asset but also on mental, physical, and social vulnerability (e. g. households with elderly members, North Korean defectors, single-parent families, youth families, elderly families, people living in dosshouses or vinyl greenhouses, comfort women (the victims of Japanese military Sexual Slavery during World War II), and men of national merit.

\subsection{Housing Conditions of Low-Income households}

\subsubsection{Inferior monthly rental housing tenants in the private rented sector}

Korea's housing tenure types are categorized into two types: homeownership and renting, which consist of chonsei, monthly rent with deposit, and monthly rent without deposit. What makes the country's renting unique is chonsei system. Chonsei contract requires a deposit of a 50 to 70 percent of the house price for enjoying a level of housing service similar to that of one's own home. In the 1970s and 1980s, at a time when Korea was going through rapid urbanization and social/political instability, landlords preferred chonsei over monthly rent because they had no way to ensure the identity of tenants. Another important role of chonsei deposits is that they play a role as a private financial vehicle for landlords. For chonsei tenants, the deposit is considered a lost opportunity cost in exchange for housing and it serves as a means of forced savings in that they can get the money back when the contract ends.

For such reasons, Chonsei became the most representative rental type in Korea. The proportion of chonsei out of total rental type reached $55 \%$ after 1980 and increased to $62 \%$ between 1995 and 2000. However, chonsei has been decreasing significantly since 2010 to $47.3 \%$, where as monthly rent with and without deposit rose to $47 \%$ (NSO, 2011).

Looking at housing tenure type by income group, the leading type for middle- and high-income households is chonsei, while 
that for low-income households is monthly rent. According to the 2012 Korea Housing Survey, the proportion of tenant house holds among the low-income group is $49.5 \%$. That of low-income households living in monthly rent with deposits $26.4 \%$ and that living in monthly rent without deposits $4.9 \%$. Considering that monthly rent accounts for only $2.7 \%$ of all tenure type and that the proportion of middle-and high-income monthly renters without deposit is around 1\% level respectively, the proportion of low-income monthly renters is very high. In particular, the proportion o $\mathrm{f}$ monthly renters in the first income decile is a staggering 6.6\% (See Table 1).

In the same vein, the percentage of homeowning low-income households is $37.9 \%$ while that of low-income chonsei tenant households is $25.5 \%$. Meanwhile, the percentages of low-income monthly renter households with and without deposit are 57.6\% and $72.7 \%$ respectively. To sum up, 7 in 10 monthly renter households are low-income families.

Considering a typical chonsei deposit represents around half the full property value, this form of renting is normally associated with better-off house holds with access to assets or the capacity to finance a deposit from a lender. Low-income renters are generally concentrated in the monthly rental sectors. The 2010 Korea Housing Survey indicates that the quality of housing services provided by chonsei rental housing is as decent as that of owner-occupied housing. Assuming that the housing size per owner-occupied households $\left(83.6 \mathrm{~m}^{2}\right)$ as 100 , that of chonsei housing is 83.9 percent $\left(70.1 \mathrm{~m}^{2}\right)$, while that of monthly rental housing with deposit is $50.1 \%\left(41.9 \mathrm{~m}^{2}\right)$ and that of monthly rental housing without deposit is $43.8 \%\left(36.6 \mathrm{~m}^{2}\right)$. Chonsei units are on the whole of better size and quality and, as Lee and Lee (2005) illustrate, most starter households prefer chonsei over monthly rent if they can afford it. The correlation between asset wealth and housing tenure is demonstrated by the 2010 Survey of Household Finances, which found the average net assets of homeowners to be 1.9 times that of chonsei tenants and 7.8 times that of monthly rent tenants (NSO, 2010). The average incomes of chonsei tenants are 84.6 percent that of homeowners, while the income of tenants living in monthly rent with deposit and pure monthly rent housing are 52.2 and 37.5 percent respectively. Essentially a hierarchy exists interms of home tenure with chonsei

Table 1. Housing Tenure Type by Income Group (as of 2012)

(Unit: \%)

\begin{tabular}{|c|c|c|c|c|c|c|c|c|}
\hline \multicolumn{2}{|c|}{ Category } & Ownership & Chonsei & Monthly rent & Monthly rent & Monthly room & Free of charge & Total \\
\hline \multirow{3}{*}{$\begin{array}{l}\text { Low- } \\
\text { income }\end{array}$} & $1^{\text {st }}$ income decile & 49.1 & 12.1 & 24.3 & 6.6 & 1.1 & 6.9 & 100.0 \\
\hline & $3^{\text {rd }}$ income decile & 48.1 & 14.8 & 30.7 & 4.1 & 0.5 & 1.9 & 100.0 \\
\hline & $3^{\text {rd }}$ income decile & 48.1 & 18.4 & 27.3 & 3.8 & 0.1 & 2.3 & 100.0 \\
\hline \multicolumn{2}{|c|}{$\begin{array}{c}\text { High-income } \\
\text { (8th-10th income decile) }\end{array}$} & 61.7 & 28.5 & 7.7 & 0.7 & 0.0 & 1.4 & 100.0 \\
\hline \multicolumn{2}{|r|}{ Total } & 53.8 & 21.8 & 18.6 & 2.7 & 0.3 & 2.8 & 100.0 \\
\hline
\end{tabular}

Source: MOLIT \& LHI(2012), The 2012 Korea Housing Survey

Table 2. The Income Distribution by Housing Tenure Type (as of 2012)

(Unit: \%)

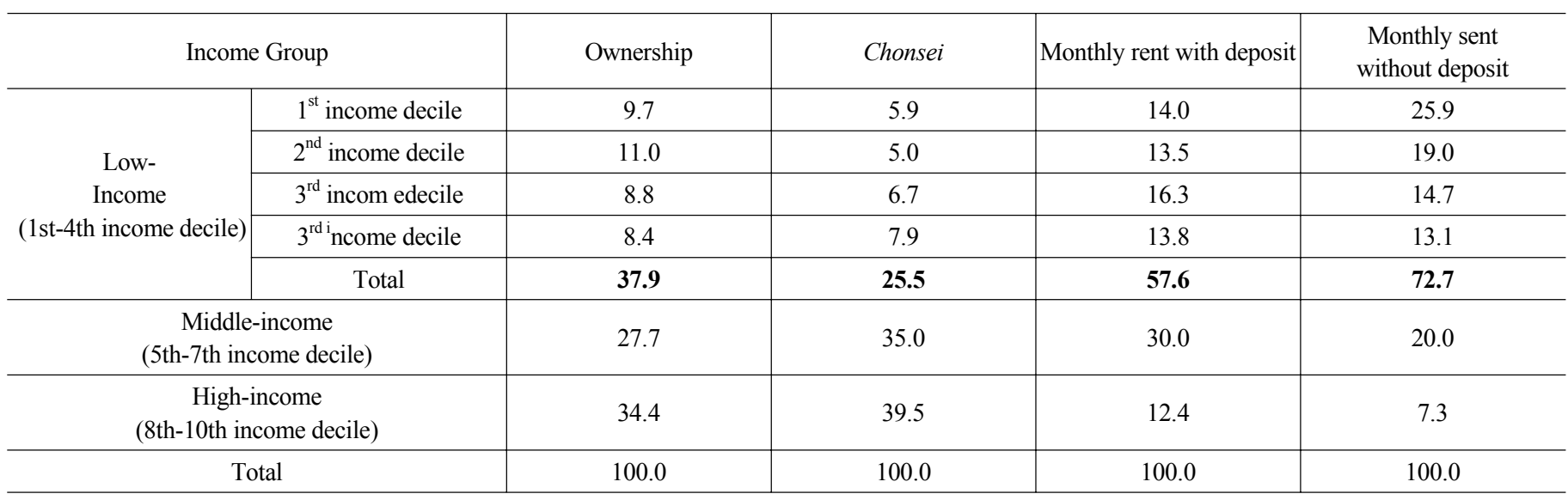

Source: MOLIT \& LHI(2012), The 2012 Korea Housing Survey 
tenants considered middle-class and monthly rent tenants as low-income households. In other words, monthly rent is generally viewed as a second option or inferior goods.

Although 'monthly rent with deposit' is a hybrid of chonsei and monthly-rent-only, it is much closer to chonsei, but with a greater variation in the share of deposit to monthly rent (e.g., 60 to 40,50 to 50 , and 40 to 60 ). Many hybrid tenure tenants have opted for smaller deposits and higher monthly rents following declining chonsei affordability with average deposits decreasing from 44 to 37 times monthly rents from 2003 to 2011.

It should be noted that the Korean rental housing market is comprised of 18 percent public sector and 82 percent private sector. Although there is the Housing Lease Protection Act that ensures the minimum two years of tenure and deposit protection, there is no lever to control increase in rent according to cyclical market changes. There is a legal limit of 5 percent on annual rent increases, but it becomes useless if the landlord refuses to renew contract with current tenant. This regulation is practically unworkable (NARS, 2011).

The average housing tenure of low-income households is very short. The tenure of owner-occupied households in one housing unit is 11 to 12 years, while that of chonsei tenants is 3years and that of monthly renters is 4 to 5years (MOLIT, 2012). The first reason why low-income tenants moved in to their current houses, they say, is 'the termination of rental contract with the previous landlord' and the second reason is 'decrease in household income', which are very different from the primary reason that middle-andhigh-income tenant households say - change in job location (MOLIT, 2012).

To sum up, under the dominance of the private rental sector, houseless low-income tenants are facing both insecurity of tenure and increasing rent burdens.

\subsubsection{Increasing housing cost burden due to increasing rent}

After chonsei price hike between 2000 and 2011, chonsei prices reached another record high in 2011. The national average increase in chonsei prices in 2011 alone was $12.3 \%$ and that of apartments was a whopping $16.2 \%$. Apartment chonsei price increase was higher than single-family housing chonsei price increase. The average annual increase in typical single-family housing between 2000 and 2011 was $6.4 \%$ while that in apartment housing was 9.2\% (Kookmin Bank, 2013). Monthly rent increased between the end of 2010 and 2011, and has been stabilized since 2012. The national average increase in monthly rent for the period between June 2010 and April 2013 was 3.6\% and that for Seoul was 2.4\% (www.onnara.go.kr).

Meanwhile, the average net income of low-income households has been nearly stagnant or increase by around $1 \%$. Over the past 11 years (2000-2011), the annual average increase in household income was $6.8 \%$ and that in wage-earner household's income was $7.1 \%$. The annual income increase of the 1 st income decile for the same time period was $3.4 \%$ with the 2 nd income decile of
$5.1 \%$, and the 3 rd income decile of $6.2 \%$-lower than the national average increase in household income. Considering the inflation rate of that period of $42.3 \%$ (3.8\% per year on average), it is no exaggeration to say that the net income of low-income households has been almost stagnant.

As the net income increase did not keep up with rent increase, the rent-to-income ratio (RIR) of low-income tenant households was significantly increased. The national average RIR rose from $22.9 \%$ of 2006 to $26.4 \%$ of 2012 , whereas that for low-income families was around $33-36 \%$. The RIR of the bottom income class reached 40-50\%. Also, low-income households facing both income poverty and asset poverty tend to switch from chonsei that requires a certain amount of saving to monthly rent with or without deposit. The ratio of chonsei tenants among low-income households went down from $18.8 \%$ of 2006 to $13.8 \%$ of 2012 , while the ratio of monthly rent with deposit rose from $20.3 \%$ to $26.4 \%$ for the same time period (StatisticsKorea, http://kosis.kr).

\subsubsection{Low-quality housing}

There is no safety gear for monthly rent rise in the private housing market and there are limitations in improving the quality of private rental housing units without government intervention. The number of housing units that do not meet the minimum housing standards has been gradually decreased from 3,340,000 units in 2000 ( $23.3 \%$ of all housing units in Korea) to $12,770,000$ units ( $7.2 \%$ of all housing units) - It shows a significant improvement. But looking at the figures in terms of income class, $72.6 \%$ of the occupiers of poor quality housing are low-income households. To be more specific, $29.6 \%$ of households living in housing that do not meet the minimum housing quality level are in the first income decile and $19.9 \%$ of the first income decile households are living in poor housing conditions. Although there is no clear definition of 'housing poverty,' we can define such households with difficulties due to their living conditions that do not meet the minimum living conditions or high housing costs relative to their household income as 'housing cost overburden.' This definition represents the housing poverty of private rental housing residents in that they are facing both high rent burden as well as poor living conditions.

\subsubsection{Limited homeownership opportunities due to high home prices}

The homeownership rate of low-income households (52.9\%) is lower than those of middle-income households $(56.8 \%)$ and high-income households $(72.8 \%)$ because many of the lowincome households cannot afford the high home prices with their low incomes and have credit constraints. On average, the house purchase cost is 11 times that of the annual average income of low-income households. This is a staggering amount considering that the PIR (Price-to-Income Ratio) of middle- and high-income households is about 5:1. That is why low-income households take more than a decade to become first-time home buyers while 
middle- and high-income households take 6-7 years (MOLIT, 2012). Moreover, their need to move frequently (4-5 times on average until they become homeowners) leads to additional emotional and economic burdens for them.

They also find difficulties in taking out loans for home purchases. Only $14.2 \%$ of low-income households can get access to financial institutions for borrowing while $30-40 \%$ of middleand high-income households can do so. This is in part because of the frequent turnover and lack of job security of low-income households. But it also implies their low credit scores and resultant difficulties in access to home loans.

\section{Housing Assistance Programs for Low-income Households in Korea}

\subsection{Overview of Housing Assistance Programs}

The number of low-income tenant households nationwide (households from the fourth income) as of 2012 is 3,374,000 households $-19.0 \%$ of all households and $45.8 \%$ of all tenant households. The stock of long-term public rental housing (for 10 year or longer) at the end of 2012 was 936,000 units, meaning that $27.7 \%$ of non-homeowning low-income tenant households are living in public rental housing.

Public rental housing has been a key housing assistance tool for low-income tenant households since 2000. The number of public rental housing in 2000 was around 300,000 units or $2.3 \%$ of all housing stock. But their number has been increased over the past 10 years thanks to steady supply, and the proportion of public rental housing units out of total housing units at the end of 2012 reached $5.0 \%$.

Public rental housing is the best solution for stabilizing constantly rising rent prices in the private chonsei/monthly rent market and for supplying quality housing at 30 to 80 percent of market prices. This is also an effect way to supply good quality housing in a short period of time when there is a shortage in affordable housing.

There is a chonsei loan assistance program that low-income tenant households can use if there is no supply of public rental housing or the type of supplied housing does not meet the demand. The low-income tenant loan program funded by the National Housing Fund is only available for chonsei tenants. This program was started in 1990 for the stable housing of urban low-income tenants. Those eligible for the program are tenants who signed a chonsei contract of a deposit less than the regional average amount and households with an income of less than twice the minimum cost of living. The amount of loan is determined based on the applicant's credit status including income and debt levels and type of collateral within 70 percent of the chonsei deposit to be paid to the landlord. The annual loan rate is $2.0 \%$, payable in 15 years. The Chonsei deposit loan program for salaried workers was started in 1994 to ensure the stable housing of tenant households and provides loans to households with an annual income of less than 30 million won (35million won for newly weds). The credit line is 80 million won per unit (within 70 percent of chonsei deposit) with an annual loan rate of $4.0 \%$, repayable by way of a bullet payment within 2 years.

Also, there is a chonsei deposit loan program for private rental housing units that project owners (local governments or LH) sign

Table 3. Financial Assistance to Chonsei Tenants Provided by the National Housing Fund

\begin{tabular}{|c|c|c|c|c|c|c|c|}
\hline \multirow[b]{2}{*}{ Year } & \multicolumn{3}{|c|}{$\begin{array}{c}\text { Chonsei deposit loan for low-income households } \\
\text { (Including existing financial assistance for } \\
\text { chonsei deposit) }\end{array}$} & \multicolumn{3}{|c|}{ Chonsei deposit loan for salaried workers } & \multirow{2}{*}{$\begin{array}{l}\text { Number of households } \\
\text { benefiting from existing } \\
\text { financial assistance for } \\
\text { chonsei deposit } \\
\text { (B) }\end{array}$} \\
\hline & $\begin{array}{c}\text { Total amount } \\
(100 \text { million won })\end{array}$ & $\begin{array}{l}\text { No. of recipient } \\
\text { households (A) }\end{array}$ & $\begin{array}{l}\text { Average loan } \\
\text { amount per } \\
\text { household } \\
\text { (Million won) }\end{array}$ & $\begin{array}{c}\text { Total amount } \\
(100 \text { million won })\end{array}$ & $\begin{array}{l}\text { No. of recipient } \\
\text { households }\end{array}$ & $\begin{array}{l}\text { Average loan } \\
\text { amount per } \\
\text { household } \\
\text { (Million won) }\end{array}$ & \\
\hline 2001 & 2,442 & 24,645 & 9.9 & 7,169 & 47,001 & 15.3 & - \\
\hline 2002 & 4,880 & 32,619 & 15.0 & 4,808 & 28,185 & 17.1 & - \\
\hline 2003 & 4,854 & 28,603 & 17.0 & 9,647 & 50,655 & 19.0 & - \\
\hline 2004 & 2,002 & 12,343 & 16.2 & 6,646 & 36,827 & 18.0 & - \\
\hline 2005 & 3,985 & 19,264 & 20.7 & 11,257 & 64,322 & 17.5 & 654 \\
\hline 2006 & 5,578 & 23,725 & 23.5 & 15,348 & 80,033 & 19.2 & 1,189 \\
\hline 2007 & 6,631 & 25,809 & 25.7 & 21,897 & 101,289 & 21.6 & 6,142 \\
\hline 2008 & 10,016 & 31,829 & 31.5 & 32,170 & 127,281 & 25.3 & 7,484 \\
\hline 2009 & 12,878 & 38,290 & 33.6 & 34,780 & 131,331 & 26.5 & 7,820 \\
\hline 2010 & 14,394 & 33,892 & 42.5 & 33,463 & 119,468 & 28.1 & 7,760 \\
\hline 2011 & 15,116 & 33,278 & 45.5 & 47,881 & 141,635 & 33.8 & 7,216 \\
\hline
\end{tabular}

Note) A includes B.

Source: MOLIT (2013a), The 2012 National Housing Fund Manual 
chonsei contracts with private landlords and that the project owners sublet the chonsei housing to low-income tenant households. This program was introduced as an alternative to Purchasing Multi-family Housing Project, which may cause side effects such as stimulating home prices in the neighborhood, difficulties in purchasing houses due to increased home prices, and subsequent increase in house purchase costs, and house maintenance issues. Under the program, low-income tenants pay a deposit of about $5 \%$ of the established amount and a monthly rent equivalent to the amount of loan interest (2\%). For example, a tenant who rented a house with a deposit of 70 million won pays only 3.5 million won as deposit and 110,000 won as monthly rent. If the required chonsei deposit exceeds the regional credit line, the excess should be covered by the tenant. Since 2008, more than 7,000 households are getting assistance from the program every year and this trend is likely to be maintained unless there is a change.

The amount of chonsei deposit loan is increasing with the rising chonsei deposit in the market. In 2010 when Chonsei prices sky rocketed by $8.8 \%$, the total number of households getting the loan assistance was decreased from 2009 but the total amount of loan provided was $1,439,400,000,000$ won. The average amount of loan per household increased from 33,600,000 won to 42,500,000 won between 2009 and 2010. The chonsei deposit loan assistance provided to salaried workers slightly decreased since 2007. Then the amount increased by $1,441,800,000,000$ won between 2010 and 2011. Among the assistance programs funded by the National Housing Fund, chonsei deposit loans began to exceed house purchase loans for salaried workers since 2007 - the ratio between the two programs was 1 to 20 in 2010 and 1 to 14 in 2011 (MOLIT,2012).

The expansion of loan assistance for chonsei tenants was part of efforts to tackle chonsei price hike. The chonsei loans provided by the public sector are a sort of interest subsidy in that their interest rates are 3 to 5 percent lower than market interest rates. According to Jietal.(2012), the chonsei deposit loan program has an effect of an interest subsidy: 1,440,000 won per year for each household (120,000 won per month) from chonsei deposit loans for low income-households and around 390,000 won (33,000 won) from chonsei deposit loans for salaried workers. Although chonsei deposit loans for salaried workers provides less amount of interest subsidy than chonsei deposit loans for low incomehouseholds, the scope of beneficiaries of the former is almost 4 times greater than that of the latter. In this regard, these two types of loan programs play a role as vouchers provided by the government to fill the gap between the policy interest rate and market interest rate.

In the case of public rental housing, YongGu Rental Housing, which are provided at prices 30 percent lower than in the market, has the same effect as offering 150,000-200,000 won(US \$130 $\$ 174$ ) to each tenant household every month and Kookmin Rental Housing, at prices 55 to 80 percent lower than in the market, has the same effect as offering 100,000-200,000 won(US \$87 $\$ 174$ ) to each household per month (MOLIT, 2012). When taking account only of financial aid for Kookmin Rental Housing excluding fund provided by the National Housing Fund, a total of 9,586 billion won(US $\$ 8.4$ billion) was provided to 789,000 households between 1999 and 2011, meaning around 12,150,000 won (US \$10,565) per household. When simply applying an interest rate of 4 percent, the amount of financial aid for each household per month is about 40,000 won(US \$35).

\subsection{Several Types of Public Rental Housing Programs}

Current rental housing market is comprised by 17.6 percent of public rental housing and 82.4 percent of private rental housing. In the public rental housing sector, the percentage of lessthan-10-year rental housing and 10-year-plus rental housing are $7.5 \%$ and $10.1 \%$ respectively. Public rental housing programs are categorized as follows: YongGu Public Rental Housing, 50-year Public Rental Housing, Kookmin Rental Housing(new construction or purchasing existing housing units), 10-year rental housing, long-term Chonsei lease, and other public rental housing programs (5-year Public Rental Housing, Lease Housing by private owners). Such a categorization is based on policy target group, rental period, and housing provider. YongGu Public Rental Housing is the lowest-cost, permanent rental-only housing for the destitute poor and the socially vulnerable. Kookmin Rental Housing is for households in the bottom four deciles of income. Public rental housing programs that only the public sector is allowed to supply are Yongu Public Rental Housing and Kookmin Rental Housing, the two programs that receive financial support from the government. And long-term lowinterest loan programs are provided for the remaining types of public rental housing. In terms of rental period, there are two types of public rental housing: housing units with rental periods of less than 10 years and those of 10 years or more. The latter are called 'long-term public rental housing' and are characterized by low-income residents as long-term rental period means better housing security. 10-year plus long-term public rental housing includes YonGu Public Rental Housing, 50-year Public Rental Housing, and new-construction-type Kookmin Rental Housing. Technically speaking, rental housing units that are supposed to be put on the market when a certain mandatory rent period expires such as 5-year public rental housing, 10-year public rental housing, and installment rental housing are not social housing. A more accurate term for them is quasi-public rental housing sector.

The reason why Korea has such a variety of public rental housing programs is, under the circumstances that there is no rent subsidy program (or income-related support) in place, to construct a housing assistance framework to meet the different needs of different income groups by differentiating rental period and rent rates. As shown in Table 4, Korea's public rental housing is defined as rental housing at rent levels below market rates. The residents are guaranteed a certain period of occupancy and 
Table 4. Type and Characteristics of Public Rental Housing

\begin{tabular}{|c|c|c|c|c|c|c|c|c|c|c|c|c|}
\hline & & & & & & Gove & rnment & Support & & & bvide & \\
\hline & & & & & & & & & & & & \\
\hline $\begin{array}{l}\text { Public Re } \\
\text { Pr }\end{array}$ & $\begin{array}{l}\text { ental Housing } \\
\text { ogram }\end{array}$ & $\begin{array}{l}\text { Start } \\
\text { year }\end{array}$ & Rent period & Supply Method & $\begin{array}{l}\text { Govern- } \\
\text { ment } \\
\text { funding }\end{array}$ & $\begin{array}{l}\text { assistance } \\
\text { (National } \\
\text { Housing } \\
\text { Fund) }\end{array}$ & $\begin{array}{l}\text { Land } \\
\text { assist- } \\
\text { ance }\end{array}$ & $\begin{array}{c}\text { Others } \\
\text { (Lottery Fund } \\
\text { Assistance) }\end{array}$ & $\begin{array}{l}\text { Tax } \\
\text { Exem- } \\
\text { ption }\end{array}$ & $\begin{array}{l}\text { Local } \\
\text { Gov. }\end{array}$ & LH & Private \\
\hline $\begin{array}{l}\text { 1. YongGu P } \\
\text { Housing }\end{array}$ & ublic Rental & 1989 & Permanent & New construction & 0 & & O & & & ○ & D & \\
\hline $\begin{array}{l}\text { 2. 50-year Pu } \\
\text { Housing }\end{array}$ & ablic Rental & 1993 & 50 years & New construction & $\bigcirc$ & 0 & & & & 0 & & \\
\hline 3. 5-year Rer & atal Housing & 1993 & 5 years & New construction & & O & O & & & & O & O \\
\hline $\begin{array}{l}\text { 4. Purchase-I } \\
\text { Program }\end{array}$ & Lease Housing & 1993 & 5 years & $\begin{array}{c}\text { New construction, } \\
\text { Purchasing }\end{array}$ & & & & & 0 & & & 0 \\
\hline 5. Kookmin & $\begin{array}{l}\text { New } \\
\text { construction }\end{array}$ & 1998 & 30 years & New construction & 0 & O & O & & & 0 & ) & \\
\hline $\begin{array}{l}\text { Rental } \\
\text { Housing }\end{array}$ & $\begin{array}{l}\text { Purchasing } \\
\text { multi-family } \\
\text { housing }\end{array}$ & 2004 & 10 years & $\begin{array}{c}\text { Purchasing } \\
\text { existing housing } \\
\text { units }\end{array}$ & & O & & 0 & & & 0 & \\
\hline & $\begin{array}{l}\text { Existing } \\
\text { housing } \\
\text { Cheonsie rental } \\
\text { housing }\end{array}$ & 2005 & 10 years & $\begin{array}{l}\text { Chonsei-Chonsei } \\
\text { of existing housing } \\
\text { units }\end{array}$ & & 0 & & 0 & & & 0 & \\
\hline $\begin{array}{l}\text { 6. Other } \\
\text { Public }\end{array}$ & $\begin{array}{l}10 \text {-year Rental } \\
\text { Housing }\end{array}$ & 2003 & 10 years & New construction & & 0 & O & & & & ○ & 0 \\
\hline $\begin{array}{l}\text { Rental } \\
\text { Housing }\end{array}$ & $\begin{array}{l}\text { Long-term } \\
\text { Chonsei } \\
\text { Housing }\end{array}$ & 2007 & 20 years & $\begin{array}{c}\text { New construction, } \\
\text { purchasing } \\
\text { existing housing } \\
\text { units }\end{array}$ & & 0 & 0 & & & & O & \\
\hline & $\begin{array}{l}\text { Installment } \\
\text { rental housing }\end{array}$ & 2008 & 10 years & New construction & & 0 & O & & & 0 & 0 & \\
\hline
\end{tabular}

Note) 50-year Public Rental Housing was government-funded between 1992-1993 only.

Long-term Chonsei Housing is rental housing provided under chonsei contracts with rental periods less than 20 years.

Installment rental housing is rental housing that the tenants pay the housing prices in installments (the tenants pay $30 \%$ of house prices at the start of occupancy, and the remainder 4 years and 8 years later, respectively. The house ownership will be transferred to the tenants 10 years after the occupancy) without having to pay security deposits. The amount of monthly rent is determined based on the amount of remainder of payment.

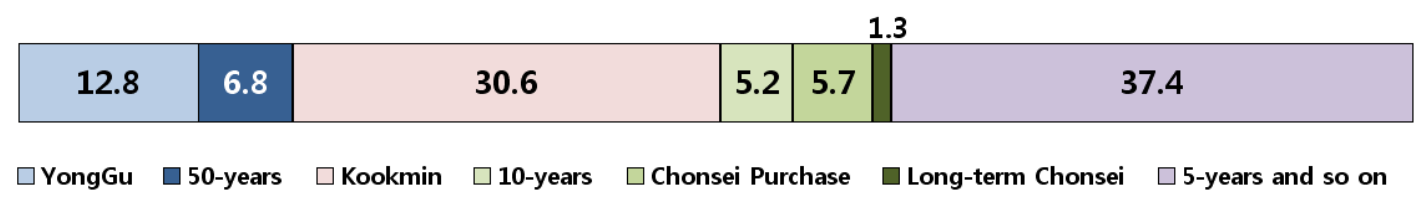

(As of the end of 2012: the Total Public Rental Housing stock=1.49 million units, Long-term Public Rental Housing Stock $=936$ thousand units)

Source: MOLIT (2013c)

Fig. 1. Composition of Public Rental Housing Stock by Type

receive government financial assistance. The private sector is only allowed to construct 5-year and 10-year rental housing.

The composition of public rental housing stock by type is shown in Figure 1. As of 2012, the public rental housing stock is $1,487,400$ units, around $8.0 \%$ of the national housing stock. The stock of 10-year-plus public rental housing is 936,000 units. The largest share is taken by Kookmin Rental Housing. Kookmin
Rental Housing, which accounts for $48.6 \%$ of 10 -year-plus long-term public rental housing, is the most major type of public rental housing. In terms of project owner, $\mathrm{LH}$ has $75.3 \%$ of long-term public rental housing and municipal governments and private project owners have the remaining $19.4 \%$ and $5.2 \%$ respectively. Among LH's public rental housing units, Kookmin Rental Housing takes the largest share of $60.4 \%$. Among municipal 
government-owned long-term public rental housing, 50-year public rental housing represents the largest share of $41.4 \%$.

Korean public rental housing programs have three characteristics: the type of public rental housing supplied differs according to income groups; the amount of government financial assistance and financial support provided by the National Housing Fund differ according to housing program; rent rates are set based on construction costs.

\subsubsection{Income-based public rental housing supply system}

The current system of public rental housing supply for low-income households is established based on income group. Households in the first and second income deciles are categorized as a group with poor housing conditions and low housing expenses affordability. The households in the first income decile are, in particular, defined as a group with low rent affordability. Households in the third and fourth income deciles are categorized as a group with low house affordability and those in the fifth and sixth income deciles as a group that can afford to buy a house if government's financial assistance is provided. As the rest of the income groups can gain homeownership status without any public assistance, their housing welfare is in the hands of the market.

In terms of housing types for different income groups, YongGu Rental Housing, Purchasing Multi-family Housing for Public Renting, and Chonsei Renting are provided to households in the first and second income decile and their rent is 30 to 50 percent of the market rates Kookmin Rental Housing is provided to households in the income bracket between the first and fourth income decile and their rent is 50 to 80 percent of the market rates.

Table 5. Long-term Public Rental Housing Stock (as of the end of 2012, $5 \%$ of the total housing units)

\begin{tabular}{|c|c|c|c|c|c|c|c|}
\hline \multirow[b]{2}{*}{ Providers } & \multirow[b]{2}{*}{ Total } & \multirow{2}{*}{$\begin{array}{l}\text { YongGu } \\
\text { Rental }\end{array}$} & \multirow{2}{*}{$\begin{array}{c}\text { 50-years } \\
\text { Rental }\end{array}$} & \multirow{2}{*}{$\begin{array}{c}\text { Kookmin } \\
\text { Rental }\end{array}$} & \multicolumn{3}{|c|}{ Other Rental } \\
\hline & & & & & 10 -years & $\begin{array}{l}\text { Long-term } \\
\text { Chonsei type }\end{array}$ & $\begin{array}{c}\text { Existing Housing } \\
\text { Chonsei }\end{array}$ \\
\hline Total & $\begin{array}{c}935,841 \\
(100.0 \%)\end{array}$ & $\begin{array}{l}190,694 \\
(20.4 \%)\end{array}$ & $\begin{array}{l}101,520 \\
(10.8 \%)\end{array}$ & $\begin{array}{l}455,107 \\
(48.6 \%)\end{array}$ & $\begin{array}{l}78,028 \\
(8.3 \%)\end{array}$ & $\begin{array}{l}19,947 \\
(2.1 \%)\end{array}$ & $\begin{array}{l}90,545 \\
(9.7 \%)\end{array}$ \\
\hline LH & $\begin{array}{c}705,063 \\
(100.0 \%)\end{array}$ & $\begin{array}{l}140,078 \\
(19.9 \%)\end{array}$ & $\begin{array}{l}26,254 \\
(3.7 \%)\end{array}$ & $\begin{array}{l}426,003 \\
(60.4 \%)\end{array}$ & $\begin{array}{l}27,100 \\
(3.8 \%)\end{array}$ & - & $\begin{array}{c}85,628 \\
(12.1 \%)\end{array}$ \\
\hline Local government & $\begin{array}{c}181,872 \\
(100.0 \%)\end{array}$ & $\begin{array}{c}50,616 \\
(27.8 \%)\end{array}$ & $\begin{array}{c}75,266 \\
(41.4 \%)\end{array}$ & $\begin{array}{c}29,104 \\
(16.0 \%)\end{array}$ & $\begin{array}{c}2,022 \\
(1.1 \%)\end{array}$ & $\begin{array}{c}19,947 \\
(11.0 \%)\end{array}$ & $\begin{array}{c}4,917 \\
(2.7 \%)\end{array}$ \\
\hline Private Company & $\begin{array}{c}48,906 \\
(100.0 \%)\end{array}$ & - & - & - & $\begin{array}{c}48,906 \\
(100.0 \%)\end{array}$ & - & - \\
\hline
\end{tabular}

Source: MOLIT (2013c).

Table 6. Government Housing Assistance for Each Income Group

\begin{tabular}{|c|c|c|c|c|c|}
\hline \multirow[b]{2}{*}{ Income Decile } & \multirow[b]{2}{*}{ Characteristics } & \multicolumn{4}{|c|}{ Housing Assistance } \\
\hline & & \multicolumn{2}{|c|}{ Supply of public rental housing } & Loan program funded by the & $\begin{array}{c}\text { Bogeumjari loan from Korea } \\
\text { Housing Finance }\end{array}$ \\
\hline $1^{\text {st }}$ & \multirow{2}{*}{$\begin{array}{l}\text { poor housing conditions and } \\
\text { low housing expenses } \\
\text { affordability ( } 1 \text { st income } \\
\text { decile: low rent afforability) }\end{array}$} & $\begin{array}{l}\text { - YongGu Rental Housing } \\
\text { - Purchased multi-family }\end{array}$ & \multirow{4}{*}{$\begin{array}{l}\text { Kookmin Rental } \\
\text { Housing }\end{array}$} & \multirow{2}{*}{$\begin{array}{l}\text { - Chonsei deposit assistance } \\
\text { for low-income households } \\
\text { (Interest rate: } 2 \% \text { ) }\end{array}$} & \\
\hline $2^{\text {nd }}$ & & $\begin{array}{l}\text { housing } \\
\text { - Existing housing Chonsei } \\
\text { rental housing }\end{array}$ & & & \\
\hline $3^{\mathrm{rd}}$ & \multirow{2}{*}{ low house affordability } & & & \multirow{2}{*}{$\begin{array}{l}\text { - Chonsei deposit assistance } \\
\text { for salaried workers } \\
\text { (Interest rate: } 4.0 \% \text { ) }\end{array}$} & \\
\hline $4^{\text {th }}$ & & & & & \\
\hline $5^{\text {th }}$ & \multirow{2}{*}{$\begin{array}{l}\text { Ability to afford to buy a } \\
\text { house if government's } \\
\text { financial assistance is } \\
\text { provided }\end{array}$} & & - Medium- and & \multirow{3}{*}{$\begin{array}{l}\text { - Loan for home purchase } \\
\text { (Interest rate: } 5.2 \% \text { ) }\end{array}$} & \\
\hline $6^{\text {th }}$ & & & $\begin{array}{l}\text { large-size rental } \\
\text { housing }\end{array}$ & & - Bogeumjari loan \\
\hline $7^{\text {th }}$ & \multirow{4}{*}{ High home affordability } & & & & (Interest rate : $5.2 \%$ ) \\
\hline $8^{\text {th }}$ & & \multirow{3}{*}{\multicolumn{2}{|c|}{ Private Market }} & & \\
\hline $9^{\text {th }}$ & & & & & \\
\hline $10^{\text {th }}$ & & & & & \\
\hline
\end{tabular}




\subsubsection{Differentiation of government financial assistance and financial support provided by the National Housing Fund}

The government is funding part of public rental housing construction projects through public funds and the National Housing Fund and is giving priority to public rental housing suppliers for buying land at low cost as well as tax cut and tax exemption benefits. Long-term public rental housing projects currently funded by the government are only YongGu Public Rental Housing and Kookmin Rental Housing. YongGu Public Rental Housing project is $85 \%$ government-funded and the remaining $15 \%$ should be paid by the residents. New constructiontype Kookmin Rental Housing get government fund ranging from 20 to 50 percent and National Housing Fund loan ranging from 37 to 42 percent commensurate with project size. Increase in financial assistance from the government and loan assistance from the National Housing Fund means reduced financial burden for the tenants and there are three categories of public rental housing by the amount of financial burden on the tenants: Type I, Type II, and Type III public rental housing programs represent $3 \%, 19 \%$, and $28 \%$ of tenants' financial burden respectively.

The terms of loan assistance from National Housing Fund for Kookmin Rental Housing are commensurate with the size of unit with a repayment period of 20 years and a grace period of 10 years. The interest rate is a flat rate of $3.0 \%$. Tenants of other public rental housing projects are also eligible for loan assistance -55 million won per $60 \mathrm{~m}^{2}$ or smaller unit and 75 million won per unit with the size of over 60 to $85 \mathrm{~m}^{2}$. The loans can be repaid for 20 years with a grace period of up to 10 years within the rental period. The interest rates are 3 or 4 percent depending on the size of unit.

It is prescribed by law that more than 40 percent of land for apartment complex construction should be reserved for public rental housing units with the size of $85 \mathrm{~m}^{2}$ or smaller and the land prices are only 60 to 85 percent of the actual land price. In addition, acquisition tax and registration tax are partially or fully exempted depending on the size and rental period of the housing unit.

\subsubsection{Cost-based rent setting system}

The terms of lease for public rental housing are determined by project owners taking account of house prices in the neighborhood under the standard terms of lease announced by the government. The standard terms of lease (regarding deposit and monthly rent) is a cost-based rent system, factoring in the construction cost at the start of construction (construction cost, land price), amount of financial and National Housing Fund assistance, repair and maintenance expenses, insurance, loan interests, taxes and the public utilities' charge, etc. Based on these criteria, LH set the rent of YongGu Rental Housing at 30 percent, Purchased Multi-family Housing for Public Renting and Existing Chonsei Rental Housing at 30 to 50 percent, Kookmin Rental Housing at 50 to 80 percent, and other public rental housing at 80 percent of the market rates.

The critical variable that determines the rent rate of public rental housing is the amount of national financial aid and assistance provided by the National Housing Fund. YongGu Rental Housing, of which 85 percent of construction cost is funded by the national fund, requires the lowest amount of rent and focus on providing housing to the poorest of the poor. Public rental housing for households in the first and the fourth income decile, such as Kookmin Rental Housing, requires differential rates of rent according to the size of housing unit, since poorer tenants are more likely to occupy smaller houses.

However, the current cost-based rent setting system also has its shortcomings of imposing different levels of rent burden for households in the same income bracket only because they live in different types of public rental housing (KDI, 2009; NABO, 2009; Jin and Kim, 2010). For example, the rent of Kookmin Rental Housing is much higher than that of YongGu Rental Housing, although it is much lower than that of the market. The average rent rate of Kookmin Rental Housing is about 5 times higher than that of YongGu Rental Housing. Also, the rent setting

Table 7. Funding Distribution Structure of YongGu Public Rental Housing and Kookmin Rental Housing

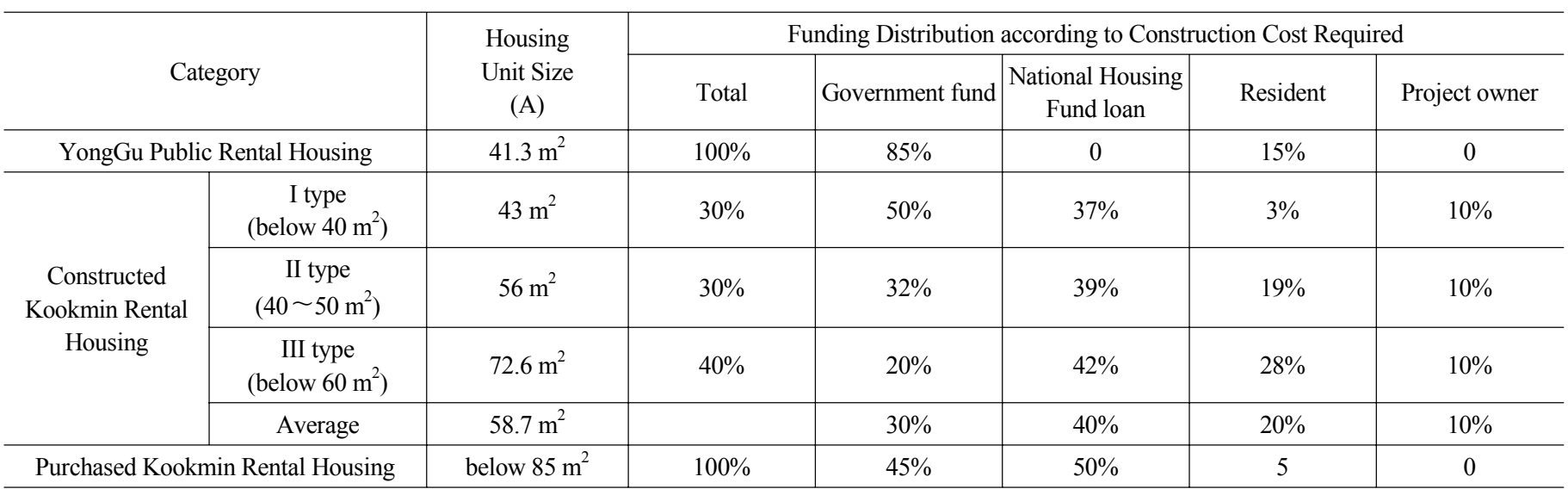

Note) The amount of financial assistance for YongGu Rental Housing and Constructed Kookmin Rental Housing per $\mathrm{m}^{2}$ is $1,820,000$ won 
criteria are different between the two types of public rental housing: Kookmin Rental Housing has a single rent setting system that applies to households in the income bracket between the first income decile and the fourth income decile (Jin, 2012). As a result, the rent of Kookmin Rental Housing is too expensive for the first income decile group and too cheap for the third and fourth income decile groups.

\section{Achievements and Limitations}

The government constructs and supplies public rental housing in order to ensure the minimum quality of housing and provide tenure stability to low-income tenants. Another important reason for doing so is that the government can stabilize the rental housing market by securing the public rental housing stock. A total of 1,340,000 units of new public rental housing $(110,000$ units per year) were newly constructed over the past 12 years (2000-2011) for rental housing market stabilization. Every time when house prices and rents soared, new public rental housing programs were introduced. Although many people voiced concern about removing the ban on development of greenbelt areas for the construction projects and environmental and traffic problems, it was always clear that the first priority is to stabilize the rental housing market through increase in public rental housing stock.

Although there is room for controversy, it appears that there is public consensus that adequate level of public rental housing stock is around 10 percent out of the total housing stocks. As the total number of long-term public rental housing units has reached 1 million, new issues concerning housing management and maintenance are emerging besides construction issues. That is why the current reform of public rental housing policy is focused on improving housing management policies.

There is not much discussion in Korea of whether public rental housing programs are more cost-effective than loan assistance programs. This is probably because there is no doubt that public rental housing is preferred over loan assistance. Providing low-interest long-term loans for partial rent payment could not ensure the tenants decent housing quality. There is no guarantee that the loans will be used for better housing quality (It is landlords, not tenants, who have control over housing quality) (Bae et al., 2008). Above all, loans should be paid back some day. Against this backdrop, this section will discuss achievements of housing assistance programs for low-income households, focusing on public rental housing supply effects and limitations.

\subsection{Public Rental Housing Supply Effects}

The effect of supply of public rental housing can be analyzed from the aspects of whether each housing assistance program met its goals: Did the program improve the quality of housing for tenants? Did the program improve the tenants' security of tenure? And how much contribution did the program make to stabilize the rental housing market?

Firstly, it was found that public rental housing had a significant effect on improving low-income households' quality of housing. About 20 to 30 percent of the public rental housing tenants said their quality of housing was greatly improved after moving into public rental housing - from underground to above ground, from communal lavatory to private bathrooms, and from run-down housing facilities to modernized ones (LH, 2012).

Secondly, public rental housing helped the low-income households to relieve rent burden. After they moved into public housing, their rent-to-income ratio significantly dropped from $30-50$ percent to $10-20$ percent. The RIR of YongGu Rental Housing tenants is 13.1\%, Kookmin Rental Housing of 181\%, Purchased Multifamily Housing for Public Renting of $13.3 \%$, and Existing Chonsei Rental Housing of $11.9 \%$. Households in the first income decile that previously lived in private rental housing saw the greatest reduction in rent burden after they moved into YongGu Rental Housing, Purchased Multi-family Housing for Public Renting, or Chonsei Rental Housing. But, as mentioned above, the rent of Kookmin Rental Housing is still unaffordable to households in the first income decile. Again, this is due to the application of a single rent setting criteria to households in various income brackets.

Thirdly, there is empirical evidence that public rental housing is contributing to the stabilization of rental housing market. Han and Nam (2006) point out that the supply of public rental housing leads to decrease in demand for private rental housing and resultant fall in rent in the short term and market stabilization in the long term. They also argue that, in the housing sub-market which has the closest connection with public rental housing, the supply of public chonsei rental housing helps stabilize chonsei apartment housing prices in the neighborhood. Sang and Oh (2009) suggest that a large-scale supply of long-term chonsei rental housing affects the fall in apartment house prices in the neighborhood. Meanwhile, there are other studies arguing that the supply of public rental housing has little impact on house prices in the neighborhood (Kim and Choi, 2009; Park and Kim, 2009; Moon et al., 2006), which means increased public rental housing is not the main cause of drop in home prices. These studies' point of view is that public rental housing construction does not necessarily give negative effects on local governments and local residents such as drop in home prices. Moon et al. (2006) point out that it is the private housing sector that causes the general public to have negative impression on public rental housing by exaggerating its negative side effects such as fall in home prices in the neighborhood, social stigma, slum formation, and poverty concentration, even thought here is no clear evidence to prove it.

A drop in home prices and rents caused by the supply of public rental housing has a positive side in that the government achieved its policy goal and a negative side in that the property value of residents in the area has decreased. Actually, local governments do not welcome the construction of public rental housing because 
of this negative impact: public rental housing construction in there would attract more number of low-income households to their districts, who are not helpful in increasing tax revenues but rather may require more welfare budget. Ultimately, the success and failure of public rental housing programs will be determined by how well the government can address their negative effects.

\subsection{Limitations}

Over the past 10 years, the government had no choice but to focus on the construction and supply of public rental housing. On the contrary, the next 10 years will be about how to manage current public rental housing stocks more effectively and efficiently, while ensuring fairness among different income categories. The limitations of current public rental housing programs can be categorized into five groups. Firstly, it is also important to answer the question of whether or not the supply of public rental housing is sufficiently covering low-income households. Currently, only one in four low-income households is living in public rental housing. Therefore, considering fairness, current public rental housing programs have limitations. In terms of the composition of residents, the proportion of households in the first income decile among YongGu Rental Housing occupants is $92.9 \%$, while that among Purchased Multi-family Housing for Public Renting is $84.5 \%$. The proportion of households in the first income decile living in Kookmin Rental Housing is a mere $15.0 \%$ whereas the that of the second income decile is $34.1 \%$, representing the largest number of occupants in this type of housing unit - the composition of Kookmin Rental Housing is fairly well balanced compared to other types of public rental housing. When it comes to the income characteristics of occupants, most of the residents of YongGu Rental Housing and Purchased Multi-family Housing for Public Renting are the poorest of the poor, while those of Kookmin Rental Housing are ranged from the first income decile to the fifth income decile and has a good social mix. On the flip side of the coin, however, Kookmin Rental Housing program is not well targeted to fulfill its mission of providing quality housing to low-income households 1 ).

Recognizing such shortcomings of Kookmin Rental Housing, the government pilot-tested the 'income-based differential rent' policy between 2007 and 2011, which intended to increase the proportion of low-income households in Kookmin Rental Housing by bringing down rent levels to the point where they can afford the public rental housing. The policy was originally designed to divide rent into four levels, but later adjusted to apply

1) Kookmin Rental Housing residence status is based on the average occupancy rate among the analysis result of 'Kookmin Rental housing Resident Satisfaction Survey' between 2002 and 2011. Purchasing-type Kookmin Rental Housing data is from that produced by Jin (2009). And the occupancy rate of public rental housing by income group is from LH's internal occupancy data at the time of contract. only two levels considering the characteristics of Kookmin Rental Housing that the proportion of self-employed workers, dayworkers, and temporary workers, whose income is hard to verify, are higher than that of salaried workers. As a result, beneficiaries of national basic livelihood and the secondary poor got a discount on rent, while ordinary low-income households paid the same amount of rent as before.

Nowadays, the issue of public rental housing affordability is coming to the fore, because the income levels of current tenants do not fit the original mission of the public rental housing (See Table 6). In order to better meet its mission and objectives, there should be sufficient level of public rental housing stock across the country. Current public rental housing system shows a mismatch between the types of rental housing supplied and the income groups that are actually living in the housing. For this reason, some are voicing the need to implement an income-related rent setting policy. And there are growing interests in demand-side subsidies.

Secondly, there is no well-established system of public rental housing management after occupancy start. The Korean government has not been actively tracking the income of low-income individuals because they do not contribute much to tax revenue increase. But from now on, the government should make more administrative efforts to track their income in order to realize universal housing welfare and minimize policy leakage. Most of all, a prerequisite for achieving the first priority of providing affordable public rental housing to low-income households is having the accurate data of their income. Currently, the occupants' income and asset levels are screened only at the time of occupancy start. But, as it has been repeatedly pointed out by state auditors, there are public rental housing residents who understate or conceal their income. In order to address such illegal actions, the government is strengthening its supervision of the residents. Under the current rent setting system for Kookmin Rental Housing, the rent that residents should pay increase until their income level reaches 150 percent of occupancy requirements. Once their income exceeds the 150 percent level, they have to move out. For YongGu Rental Housing, the rent goes up by 20 percent every time they renew their contracts ( 10 percent for the secondary poor) until it becomes equivalent to the rent for Kookmin Rental Housing. However, there are not many households that are moving out due to income increase. The annual turnover rate of public rental housing over the past 3 years was 4 to 8 percent. That of some YongGu Rental Housing complexes in Seoul, where there is only a small stock of YongGu Rental Housing, is only 3.5\%. And that of YongGu Rental Housing and Kookmin Rental Housing in other regions is 5 to 8 percent. These turnover rates are not that low, but it should be noted that the turnover is not as active as it should be. The 2011 survey of rental housing residents indicates that the proportion of residents whose income exceeds the level of the fifth income decile among YongGu Rental Housing occupants was 3.1\%, with Kookmin 
Table 8. The RIR of Public Rental Housing Residents

\begin{tabular}{|c|c|c|c|c|c|c|}
\hline \multirow{2}{*}{ Category } & \multirow{2}{*}{$\begin{array}{l}\text { YongGu Public } \\
\text { Rental Housing }\end{array}$} & \multirow{2}{*}{$\begin{array}{l}\text { 50-years Public } \\
\text { Rental Housing }\end{array}$} & \multicolumn{2}{|c|}{ Kookmin Rental Housing } & \multirow{2}{*}{$\begin{array}{c}\text { Existing Housing } \\
\text { Chonsei }\end{array}$} & \multirow{2}{*}{ Private rental housing ${ }^{3)}$} \\
\hline & & & New construction-type & Purchasing-type & & \\
\hline $\begin{array}{l}\text { Average RIR } \\
(\text { as of 2011) }\end{array}$ & 13.1 & 21.6 & 18.1 & 13.3 & 11.9 & 22.0 \\
\hline $\begin{array}{l}\text { RIR by income } \\
\text { class }\end{array}$ & $\begin{array}{c}\text { National basic living } \\
\text { cost recipient: } 12.4 \%, \\
\text { Non recipient : } \\
10.0 \%{ }^{2)}\end{array}$ & - & $\begin{array}{c}2003-2011 \\
\text { Average : } 6.4 \%-20 \% \\
\text { The first bottom decile : } \\
44.7 \% \\
\text { The second bottom } \\
\text { decile : } 22.0 \% \\
\text { The third bottom decile : } \\
16.0 \% \\
\text { The fourth bottom decile } \\
: 13.5 \%\end{array}$ & - & - & $\begin{array}{l}\text { The first bottom decile: } 45.9 \% \\
\text { The second bottom decile : } 33.2 \% \\
\text { The third bottom decile : } 22.7 \% \\
\text { The fourth bottom decile: } 18.1 \%\end{array}$ \\
\hline
\end{tabular}

Note 1) MLTM and KRIHS (2011)

2) Based on KOCER's YongGu Public Rental Housing Survey (2005)

3) MLTM and KRIHS (2010)

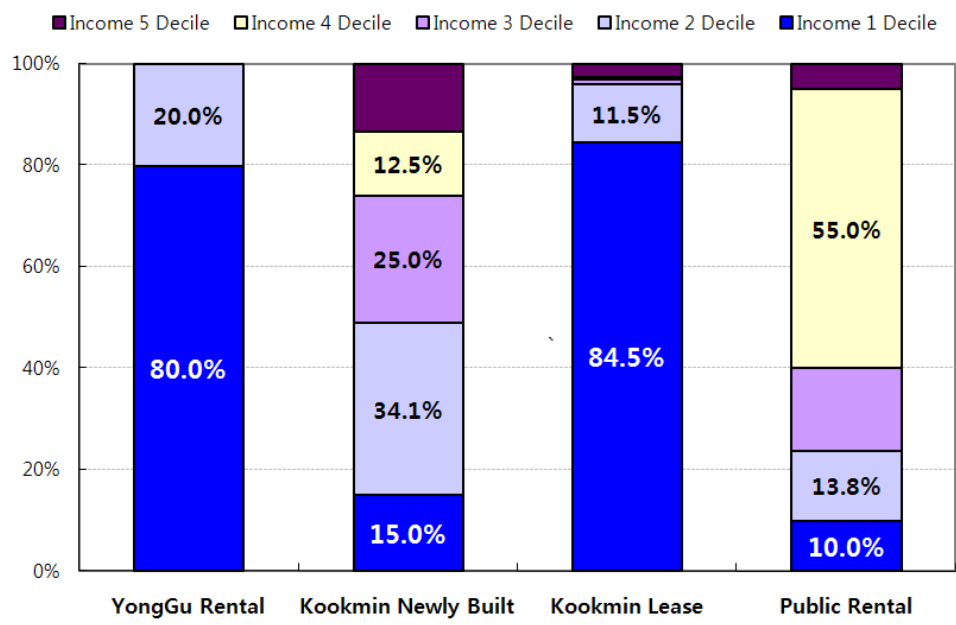

Source : YongGu Public Rental Housing residence status is from LH's internal data. New construction-type

Fig. 2. The Ratio of Public Rental Housing Residents by Income Group (\%)

Rental Housing of 25.6\%, Purchased Multi-family Housing for Public Renting of 5.6\%, and Existing Chonsei Rental Housing of $12.7 \%$. Therefore, policy tools to ensure the fair distribution of public rental housing services to those in need should be developed and implemented.

The third limitation is the inflexibility of rent system for public rental housing. The rent rate is fixed at the time of construction regardless of subsequent environmental changes. As most of public rental housing complexes are constructed in rural areas with cheap land, their construction costs are relatively low. The construction of large-scale housing complexes leads to improvements in infrastructure and transportation service quality. Most of the public rental housing complexes built 10 years ago in deserted rural areas are now transformed into bustling secondary centers. Meanwhile, their rent has been raised by 1 percent per annum.
The rent was frozen at the time of bad economy and there have been many difficulties in raising rent considering the large population of extremely poor residents. As a result, YongGu Rental Housing complexes' rent versus the market average, which used to be about 30 percent at the time of construction, is only 23 percent as of the end of 2012. That in regions where the home prices are high including Seoul is only around 10 percent. Meanwhile, the construction costs for new housing complexes as well as maintenance costs for existing complexes that project owners should bear are constantly increasing. And rent coming from public rental housing is not sufficient to cover the costs. As the project owners receive financial support for the construction of housing complexes but not for maintenance, the increasing stock of public rental housing is putting a large financial strain on them. In this regard, the financial viability of project owners is 
one of the outstanding issues.

The fourth limitation is the fairness of housing assistance between beneficiaries and non-beneficiaries. And as it was mentioned above, there is an issue of fairness among beneficiaries. Under the current rent setting system, individuals with higher income receive more benefits. But, what is more important is its "take one, take all" requirement. Various social organizations, schools, religions organizations, and private companies are providing a wide range of assistance such as food, clothes, and medical services to public rental housing complexes where the poorest of the poor are living in. It means that once the occupants face eviction from the public rental housing, they no longer have access to such material benefits. Such a situation also restricts the asset growth of the residents. Therefore, we need to redesign current public rental housing policies in a way that opens the door to the poor who cannot afford public rental housing and that provides the occupants with opportunities to climb the social ladder.

The fifth limitation is the lack of participation of local governments and the private sector in public rental housing supply. As discussed above, many local governments are unwilling to construct new public rental housing for the fear of increased financial burden even though they have public responsibility to meet local housing needs. Universal welfare requires universal burden-sharing, but current situation shows that the former is stressed while the latter is neglected.

Currently, the private sector is allowed to participate in only 5-year and 10-year public rental housing construction projects among all the public rental housing programs. Even though the government offers cheap land and National Housing Fund assistance, the participation rate of the private sector is very disappointing. Meanwhile, many 5-year rental housing projects constructed during the second half of the 1990s by the private sector went bankrupt or were delayed due to the 1998 Asian financial crisis, causing damages to the prospective residents. Even though such cases have seriously damaged the credibility of the private sector, attracting private capital to rental housing construction is not an option that can be ruled out. Above all, the construction of public rental housing requires a lot of financial resources and the diversity and ideas of the private sector. The government is considering various methods including BTL and land-leasehold rental housing construction to draw the active participation of the private sector.

\section{Conclusion and Suggestion}

This paper took a look at current housing assistance programs for low-income households in Korea, the types and characteristics of public rental housing identified during the public rental housing policy implementation process, and their policy achievements and limitations. Korean housing assistance programs are characterized by public rental housing. Public rental housing programs started relatively late compared to other countries because of the country's unique rental system of chonsei, as discussed in Section 2. Currently, the proportion of chonsei contracts is continuously shrinking while a majority of tenant households still prefer chonsei over monthly rent. Therefore, the overheating of the chonsei market is likely to be continued for some time. In order to meet the demand of tenant households for chonsei rental housing, the government is increasing the supply of chonsei-type public rental housing.

The homeownership rate in Korea is 54 percent, lower than the EU average of 68.6 percent and OECD average of 64 percent. The rate of Korean low-income households is even lower than that. However, there are limitations in expanding credit lines to tenants considering the huge amount of household debts and the low possibility of income/asset growth of low-income households. In this regards, it is unlikely that the homeownership rate would be further increased, and that is why the government's role in meeting their rental housing needs is all the more important.

While it is obvious that the supply of public rental housing will remain the first policy priority in the future, the revision and improvement of current public rental housing programs should not be neglected.

The present government has introduced its new public rental housing project called "Happy Housing Project," to provide decent housing to college students, recent college graduates, and newlyweds. This project includes the construction of public rental housing near business areas for short commute distances and various cultural facilities. But the types of housing are nothing new: YongGu Rental Housing, Kookmin Rental Housing, Purchased Multi-family Housing for Public Renting, and existing Chonsei Rental Housing. Therefore, it is necessary to realign and integrate new and existing public rental housing projects and to comprehensively revamp the occupancy requirements, management standards, and rent rates. Also, the current LHdriven supply of public rental housing should be changed toward public-private partnership. The central government should provide more initiatives to local governments in order to encourage them to meet local housing needs and promote more active participation of the private sector in public rental housing programs.

\section{References}

1. Bae, Soon-Soek et al. (2008), Evaluation of the Housing Welfare Policies for low-income Households in the 2000's and New Policy Directions, KRIHS.

2. Han, Chang-Ok and Jin Nam (2006), "An Analysis on The Housing Market Impacts by The Supply of The Public Rental Housing”, Research Seminar of the Korea Real Estate Analysis Association (published by Korea Planners Association), 1003 1012.

3. Jin, Mee-youn (2012), A Study on the Rent Adjustment of Long-term Public Rental Housing, LHI Report.

4. Jin, Mee-youn and Kung-Sun Kim (2010), An Evaluation on the 
'Income-Retalted Rent' Pilot Project applied by National Public Rental Housing, LHI Report.

5. KDI(Korea Development Institute) (2009), Kookmin Rental Housing Construction Assistance Project-2008 Government Project In-depth Evaluation Report.

6. Kim, Joo-Jin and Mack-Joong Choi (2009), "External Effects of Public Housing on Neighborhood Housing Prices in Seoul -An Application of Multi-level Hedonic Price Model with Social Mix Types Included-", Journal of the Korea Planners Association, 44(1): $101 \sim 111$.

7. Kookmin Bank (2013), National House Price Survey Data.

8. Korea Land and Housing Corporation(LH) (2012), Public Rental Housing Resident Satisfaction Survey.

9. Lee, Sanh-Il and Chang-Moo Lee (2005), "Differential housing demand by renter's choice between chonsei and monthly rent with variable deposit", Housing Studies Review (the Korean Association for Housing Policy Studies), 14(1): 139 163.

10. MOLIT(Ministry of Land, Infrastructures and Transport) (2013a), A Handbook of 2012 National Housing Fund.

11. MOLIT(Ministry of Land, Infrastructures and Transport) (2013b), A Handbook of 2012 National Housing Policy.

12. MOLIT(Ministry of Land, Infrastructures and Transport) (2013c), http://stat.molit.go.kr
13. MOLIT(Ministry of Land, Infrastructures and Transport) (2012), Report for Results of 2012 Housing Condition Survey.

14. MLTM and KRIHS (2011), Report of 2011 Housing Condition Survey- Tenant Survey in Rental Housing.

15. Moon, Jang-Hyuk, Kyung-Chon Seo and Sung-Ho Lee (2006), "A Study of The Influence of Public Housing on The Land Price of Community", Journal of the Korea Planners Association, 41(4): $103 \sim 114$.

16. NABO(National Assembly Budget Office) (2009), The evaluation on the National Public Rental Housing.

17. NARS(National Assembly Research Service) (2011), "Domestic and International Trends of Rent Regulations and Their Implication", NARS Policy Issue Report, 119.

18. NSO(National Statistics Office) (2010), 2010 Survey on the Financial Status of Households (December 29 Press release).

19. NSO(National Statistics Office) (2011), 2010 Population and Housing Census- Household and Housing part (July 7 Press release).

20. Park, Kwan-Min and Ho-Cheol Kim (2009), "A Study on The External Effect of Public Rental Apartment", Journal of the Korea Real Estate Analysis Association, 15(3): 127 147.

21. Sang, Nam-Kyu and Dong-Hun Oh (2009), "A Study on The Effect of SHift Project on The Housing Price", Journal of the Korea Real Estate Analysis Association, 15(2): 149 165. 